\title{
LEONI AND HAYEK ON NOMOS AND PHYSIS
}

\author{
by Raimondo Cubeddu
}

\section{Preface}

As he distributed a series of 'Handouts' to his law students in 1949 entitled Lessons in the Philosophy of Law: Ancient Thought, with an Appendix on Christian Thought ${ }^{1}$, Bruno Leoni could not have imagined that he was laying the groundwork for a radical reformulation of the tradition of 'true Individualism', to use the term which Friedrich A. von Hayek coined later that year ${ }^{2}$. This was no less than a new history of the origins and development of the liberal tradition, a revisionist account that would enjoy widespread success, and that, in the Hayek's

Dipartimento di Civiltà e Forme del Sapere, Università di Pisa.

The author would like to thank Jake Dyble for his invaluable contribution to the translation of this article.

1 See B. Leoni, Lezioni di Filosofia del Diritto. Il pensiero antico, con Appendice sul pensiero cristiano, Pavia-Milano, Editrice Viscontea, 1949, pp. 128+28; henceforth, the quotations are from this edition. The work is now available in B. LEONI, Lezioni di filosofia del diritto e di dottrina dello Stato, in B. LEONI, Opere Complete, vol. III, with an introductory essay by L. Infantino, Torino, IBL Libri, 2020 epub, as well as in a standalone edition with the title Il pensiero antico. Lezioni di filosofia del diritto, with an introductory essay by C. Pelloso, Note gius-grecistiche a margine delle Lezioni sul pensiero antico di Bruno Leoni, Torino, IBL Libri, 2020 (forthcoming). The Handouts contain many Greek and Latin quotations, some left untranslated and some translated by Leoni himself.

2 In Individualism: 'True' and 'False', originally intended as the introductory essay to F.A. HAYEK, Individualism and Economic Order, London, Routledge, 1948 (this work, reviewed by B. LEONI in "L'Industria", n.1, 1950, pp. 145-147, represents Leoni's first contact with the Austrian School). The marginal notes that Leoni added in pencil to his own copy of the Hayek's book (now in my possession) demonstrate the attention and interest with which Leoni read the work. 
formulation, was destined to alter 'The Fortunes of Liberalism' in the twentieth century3.

After describing the origins of the concepts of nomos, physis and thesis in Greek philosophy, Leoni alights upon the Epicurean solution and its doctrine of contract, not only as the resolution of that antithesis, but also and above all as something of revolutionary import that gave rise to a doctrine

"Of exceptional importance for subsequent conjecture on the law and the modern state: the doctrine of contract as fundamental to the political community, and to legislation in general, that even in its abstraction and in its imprecision constituted, for medieval thought and above all for modern thought, the departure point for a series of exceptionally fruitful developments"4.

Leoni, unfortunately, did not indicate what those 'developments' might be, either in the Handouts or in his subsequent works, though these ideas and the theories find echoes in the words of 'Our Mission' [Il nostro compito] which prefaced the first edition of "Il Politico" in 1950. Nevertheless, it can be deduced without much difficulty that these 'exceptionally fruitful developments' were substantially outlined by Carl Menger, Investigations into the Method of the Social Sciences with Special Reference to Economics. They were developments that Hayek, in the wake of Menger's work, had understood as the principal problem of the 'theoretical social sciences's. Hayek here identified one approach that he defined 'true Individualism' and another which he termed 'false Individualism', a theory which saw institutions arising from the will of specific

3 This is also the title that would be given to a collection of F.A. HAYEK's essays in The Collected Works of F. A. Hayek, ed. by P.G. Klein, vol. IV, Chicago-London, The University of Chicago Press-Routledge, 1992.

4 Leoni, Lezioni di Filosofia del Diritto. Il pensiero antico, cit., p. 129.

5 See C. Menger, Untersuchungen über die Methode der Socialwissenschaften, und der Politischen Oekonomie insbesondere, Leipzig, Duncker \& Humblot, 1883, now in The Collected Works of Carl Menger, edited, with an Introduction: Carl Menger, by F.A. von HAYEK, London, The London School of Economics and Political Science, 1933-1936, vol. II; Engl. trans. Investigations into the Method of the Social Sciences with Special Reference to Economics, with a new Introduction by L.H. White, New York-London, New York University Press, 1985. 
individuals and specific social groups, interpreting them as the result of will and design'.

In 1968, commemorating Leoni on the anniversary of his disappearance, Hayek remarked that the way in which Leoni had talked "of the relation between physis and nomos in ancient Greek thought seems to me to contain much that would deserve development"7. This, incidentally, demonstrates that Leoni continued to cleave to the ideas outlined in his Handouts, and had sought to bring them to a wider audience. But when Hayek, in "Rules and Order", drawing on Menger's distinction between "institutions created pragmatically and institutions created unintentionally", rediscovered therein the origin of the famous antithesis that the Greeks had instituted between nomos and physis, or between cosmos and taxis, he did not refer to Epicureanism, nor to the importance that Leoni attached to its doctrine of contract, nor to Leoni's Handouts. Hayek rather considered this interpretative tradition to have originated by and large in the work of Bernard de Mandeville. From here he traced it down to Menger, who, in fact, had considered it to have arisen several decades after Mandeville: with Charles-Louis de Montesquieu and, above all, with Edmund Burke and Friedrich C. von Savigny.

Leoni and Hayek were interested in the way in which, in the modern period, there arose and developed a theory of the birth, character, evolution, and functions of those institutions which constitute

6 See F.A. HAYEK Individualism: 'True' and 'False', cit., Having reconstructed its origins, B. Caldwell has now republished it in F.A. HAYEK, Studies on the Abuse and Decline of Reason: Text and Documents, ed. by B. Caldwell, in The Collected Works of F.A. Hayek, vol. XIII, The University of Chicago Press, Chicago, 2010.

7 See F.A. HAYEK, Bruno Leoni the Scholar, in P. SCARAMOZZINo (ed.), "Omaggio a Bruno Leoni", Quaderni della Rivista "Il Politico", 1969, pp. 25-26, and now also as Bruno Leoni (1913-1967), in F.A. HAYEK, The Fortunes of Liberalism, cit., p. 257. On that occasion, Hayek wrote that "It is particularly to be regretted that he did not find time to prepare for publication the suggestive and original first volume of his Lezioni di filosofia del diritto which deals with the thought of classical antiquity and which in 1949 he had issued in mimeographed form for his students. His treatment of the relation between physis and nomos in ancient Greek thought in particular seems to me to contain much that would deserve development".

8 Now in F.A. HaYeK, Law, Legislation and Liberty, 1973-79, vol. I, ed. London, Routledge, 1982. An important study by J. Shearmur on this theme with the title Hayek, Leoni and the Rule of Law, is forthcoming. 
what is probably the principal object of the social sciences. But at the same time, in 1949, in Human Action, a volume that Leoni would review ${ }^{9}$ and which Hayek could hardly ignore, Ludwig von Mises, another exponent of the Austrian School, defined "the philosophy of Epicureanism" as that tradition which, by means of "the theory of the division of labour" had produced "the complete demolition of all metaphysical doctrines concerning the origin and the operation of social cooperation", inaugurating and realizing "the spiritual, moral, and intellectual emancipation of mankind" and substituting "an autonomous rational morality for the heteronomous and intuitionist ethics of older days" 10 .

A few years later, another philosopher, Leo Strauss, was also dwelling on the origins of modernity and on the associated birth of a new political philosophy, one that presented itself as a new way of understanding the ends and functions of 'the best political regime'. He was approaching the problem from a different direction of course, very different in fact: Strauss had little to do with Leoni, Mises, and Hayek, whom he never cites ${ }^{11}$. Yet after having described in the thirties the

9 See "L'Industria", n. 3, 1950, pp. 469-475.

${ }^{10}$ L. Mises, Human Action. A Treatise of Economics, del 1949, ed. Auburn, Ludwig von Mises Institute, 1998, p. 147. In its entirety, the passage reads: "The historical role of the theory of the division of labor as elaborated by British political economy from Hume to Ricardo consisted in the complete demolition of all metaphysical doctrines concerning the origin and the operation of social cooperation. It consummated the spiritual, moral and intellectual emancipation of mankind inaugurated by the philosophy of Epicureanism. It substituted an autonomous rational morality for the heteronomous and intuitionist ethics of older days. Law and legality, the moral code and social institutions are no longer revered as unfathomable decrees of Heaven". This peremptory affirmation can be considered the summation of the references to Epicureanism made by Mises in previous work, see R. CuBEDDu, Individualismo e religione nella Scuola Austriaca, Pisa, Edizioni ETs, 2019, pp. 24ff., and R. CUBEDDU, Epicureismo e individualismo, forthcoming.

11 Given that investigations conducted in the archives at Pavia and Chicago have not turned up any hint of correspondence, it is impossible to know when and how Leoni came into contact with Strauss. We only know that in the section entitled 'Attività dell'Istituto' in "Il Politico", n. 3, 1953, p. 384, referring to his visit to Chicago on 3rd November 1953 and a conference he held there on "Political and intellectual trends in Italy" (a topic unlikely to have interested Strauss), Leoni wrote that Enrico Fermi, Strauss, and Hayek also contributed to the discussion. Given that in these years Leoni was close to the activities of the Fondazione Olivetti, and that his collaborator, Franco Ferrarotti, who had studied in Turin, was in Chicago and regularly visited Strauss (see A. GNOLI, Intervista a Franco Ferrarotti, in La Repubblica, 27/01/2013), we can guess that it was Ferrarotti who put them in contact. 
However it happened, in 1954, B. LEONI reviewed L. STRAUSS's volume Natural Right and History, Chicago, The University of Chicago Press, 1953, in "Il Politico", 1954, p. 131, contesting its judgment on modern political science and on Max Weber, but also writing of Strauss that his "deep knowledge of the history of the concept of natural law cannot be denied, nor the fierce and refined dialectic with which he defends the concept against the assault, by now almost considered fatal, of historicist criticism", and that "whatever ideas the reader might have about this essay, is must be observed that it represents a precious contemporary contribution to the theory and history of the concept of "natural law", a contribution that cannot be ignored even by the numerous critics of the same concept". In 1956, once more in "Il Politico", n. 3, pp. 359-373, it seems the first part of the then essay of Strauss appeared, entitled What is Political Philosophy?, of which existed only a summary in Hebrew translation "Iyyun. Hebrew Philosophical Quarterly" (Jerusalem), 6, no. 2 (April), and that would appear subsequently with the same title only in 1959 in L. Strauss, What is Political Philosophy? and Other Essays, Glencoe, Ill., Free Press (recalling on p. 5 the first publication of What is Political Philosophy in "Il Politico"). The essay, with the title Che cosa è la filosofia politica, appeared in the section "Notes and Discussions' and was presented as a "translation from the original English" (a sign that Leoni had received it from Strauss), and with the following preface: "From Leo Strauss, professor at the University of Chicago, a scholar of international renown and author of essays which now have to be considered of essential importance on Hobbes, on the relationship between natural law and historicism, and not least, on Machiavelli, we are honoured to publish the following note, the conclusions of which, with regard to political science, while strongly polemical and perhaps irreconcilably opposed to the opinions which animate this journal, deserve our attentive examination, and suggest an opportunity of presenting a response, which is envisaged to appear in one of the forthcoming editions". The fact that Strauss talks of Machiavelli only in the third part of What is Political Philosophy (and not in the first version published in "Il Politico") and the fact that the first Straussian essay on Machiavelli appears in 1957, suggests that Leoni had a direct relationship with Strauss. Leoni's response would arrive, as we shall see, the following year, see B. LEONI, Giudizi di valore e scienza politica, in "Il Politico", n. 1, 1957, pp. 86-94. The essay, presented as a translation of a "speech made by the author at the Manchester Social Science Club on 14 February 1957", contains discussion of Straussian ideas which are not present in the first part of L. STRAuSs, What is Political Philosophy?, cit., but which appear in subsequent essays, for example in L. Strauss, An Epilogue, del 1962, now in L. STRAuss, Liberalism Ancient and Modern, 1968, Ithaca-London, Cornell University Press 1989, pp. 203-223.

We likewise do not know how Leoni behaved in a seminar on 'Relativism' in 1960, in which Mises and Strauss among others participated (respectively B. LEONI, Some Reflections on the "Relativistic" Meaning of Wertfreiheit in the Study of Man; L. MisES, Epistemological Relativism in the Sciences of Human Action; and L. STRAUSS, Relativism, in H. Schoeck, J.W. Wiggins (eds.), "Relativism and the Study of Man", Princeton, Van Nostrand, 1961), which, as is written in the Preface, p. vii, was characterised by "formal and informal discussion of his own and other papers" and by "lively and frank disagreements posed by differences of approach or interpretation". Details on this symposium are also provided by the 'reports' on each talk made for the Wolker Foundation by M.N. RотнBARD (who assisted) and now in Murray N. Rothbard vs the Philosophers. Unpublished Writings on Hayek, Mises, Strauss, and Polanyi, edited with an Introduction and Notes by R.A. Modugno, Auburn, Ludwig von Mises Institute, 2009. Rothbard refers to a "famous battle at this symposium between Leoni and Mises on the one side and Strauss on the 
influence of Epicureanism in the formulation of the Spinozian "critique of religion", he would write about Thomas Hobbes (whom Hayek, in his own essay on the doctrine of contract, had placed, together with René Descartes, at the origins of that "Constructivist rationalism" which he was juxtaposing with "true Individualism") and would maintain that with Hobbes the Epicurean doctrine of pleasure had been transformed, and that on this foundation that was built the conjunction of atheism and political hedonism which had "revolutionized human life everywhere on a scale never yet approached by any other teaching"12. This 'revolution', in a manner undoubtedly different and with different emphasies, had transformed that politics which the ancient Epicureanism had disdained as much as it did business, into the producer or guarantor of that long-lasting enjoyment of the frugal pleasures that for the followers of the Garden was identified with ataraxia (the 'inner peace' that the moderns substitute with 'social

other" (p. 105). This 'battle', that also raged over assessment of Weber (loved by Leoni, scorned on the other hand by Strauss - see R. CuBEDdu, Saggio introduttivo to E. von BÖHM-BAWERK, "La conclusione del sistema marxiano", Torino, IBL Libri, 2020, p. XL, n. 51 - and criticised by Mises for his economic theories and theories on human action), is referred to by Rothbard who notes "some emotional disagreements between Mises, Leoni, and Strauss", p.115. The scene was probably set for this show down from the moment that Mises had written in L. Mises, Theory and History: An Interpretation of Social and Economic Evolution, del 1957, New Rochelle, ed. Arlington House, 1969, pp. 299ff. and nn., about the Straussian conception of value judgments with reference to what he had written in L. STRAuss, Natural Right and History, cit..

On Leoni and Hayek see A. Masala, Il liberalismo di Bruno Leoni, Soveria Mannelli, Rubbettino, 2003. Strauss and Hayek were both teaching at Chicago in the 50s and, though it appears they were not in regular contact, they did meet at least once. A. EBENSTEIN, in Friedrich Hayek. A Biography, New York, Palgrave-St. Martin Press, 2001, p. 253, in order to prove that Hayek and Strauss were not in regular contact, cites the evidence of Joseph Cropsey (who was Strauss's student and collaborator and who knew Hayek), who "remembers no contact at all between Hayek and Strauss in Chicago". However, another student and collaborator of Strauss G. ANASTAPLO, in Leo Strauss at the University of Chicago, in K.L. Deutsch, J.A. Murley (eds.), Leo Strauss, The Straussians, and American Regime, Lanham, Rowman \& Littlefield, 1999, pp. 24, n. 7, does mention contact between the two. A letter of K. Löwith to Strauss, dated 25 settember 1952 reads thus: "Schade dass Sie nicht auch mit in Alpbach waren. Ich traf dort Bergsträsser und Hayek ect." (cfr. L. STRAUSS - K. Löwith, Korrespondenz Leo Strauss - Karl Löwith, ora in L. STRAuss , Gesammelte Schriften, Bd. 3, Hrsg. von H. und W. Meier, Stuttgart, Metzlersche Verlagsbuchhandlung und Carl Ernst Poeschel Verlag, 2001, pp. 678-79). It seems that Löwith takes it as read that they were acquaintances.

12 See L. StRAuss, Natural Right and History, cit., p. 169. 
peace'). This was understood by Epicureans as a fundamentally individual objective: an objective that might be termed 'moral' but certainly not 'political', though it could be obtained together with friends as part of a free and reciprocal collaboration.

In contrast to what Menger had done and what Hayek was doing, Leoni, Mises, and Strauss were pointing to Epicureanism as the father of the 'individualistic' turn in modern political philosophy, albeit independently and for different and perhaps opposing motives. As he developed his own interpretation of the origins and characteristics of the tradition of "true Individualism", however, Hayek took no account of the ideas of Leoni and Mises on its origins. Given that the thinkers indicated by Hayek as the founders of the theory of institutions as the unintentional outcomes of individual actions, Mandeville and David Hume, were by no means indifferent to Epicureanism to say the least, we might look to add something on the origins of that theory, beginning with Leoni's writings in his Handouts on conceptions of law in ancient Greece. Leoni's conceptualization posits a long period opposition

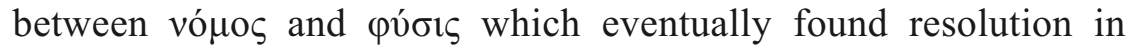
Epicureanism, and has for its object the origin and the nature of juridical and political obligation.

Notwithstanding the importance he had attached to it, Epicureanism vanished from Leoni's philosophical horizons in his subsequent general writings ${ }^{13}$, which in the same period began to converge with the themes outlined by the Austrian School. But to infer from this that no trace remains of his intuition on the influence of Epicureanism ${ }^{14}$ is something

${ }^{13}$ See B. Leoni, Freedom and the Law, 1961, Indianapolis, Liberty Fund, 1991; B. LeONI, Lezioni di filosofia del diritto e di dottrina dello Stato, cit., and B. LeONI, Il pensiero politico moderno e contemporaneo, ed. by A. MASALA and with Introduction by L.M. BASSANI, Macerata, Liberilibri, 2008.

${ }^{14}$ Limiting ourselves to works existing in the years in which Leoni was writing, it can be observed that J.-M. GUYAU in La Morale d'Épicure et ses rapports avec les doctrines contemporaines, Paris, Libraire Germer Baillière, 1878, and A. FALCHI, in Il pensiero giuridico d'Epicuro, Sassari, Satta, 1902 (a work which acknowledges the influence of Guyau) develop the relationship between Epicureanism, Thomas Hobbes, and English utilitarianism from a 'continuist' perspective', and that V. BROCHARD, in La théorie du plaisir d'après Epicure, 1904, now in V. BROCHARD, Etudes de philosophie ancienne et de philosophie moderne, Paris, Vrin, 1926, had tackled the same topic in a 'discontinuist' key. However, in Chapter VII, of $I l$ pensiero antico, cit., dedicated to the juridical theory of Epicureanism, B. LEONI mentions, without indicating their names and works, only Ettore 
of an exaggeration if one considers the theory of exchange of demands and powers that Leoni would develop in the seventies ${ }^{15}$.

We will therefore re-examine the theories of Leoni and Hayek on the birth and evolution of Right, of its relationship with Law and with its 'political producers', and on the foundation and justifications of obedience to positive law. We will also consider the theories of Menger ${ }^{16}$, who, when he deals with the "organisch-unreflectirt" birth of social institutions, including law, does not talk of physis and of nomos but seems to have in mind the Roman Law and, not coincidentally, cites Savigny. It should be recalled that Leoni and Hayek were strenuous critics of Hans Kelsen, who they considered the greatest exponent of that legal positivism that saw the 'legal system' as a 'political production' 17 .

Bignone, Pierre Gassendi, Theodor Gomperz, Robert Philippson, Hermann Usener, and Eduard Zeller. In this respect it should be recalled that other works of Falchi - also a professor of philosophy of law - are cited by B. LEONI in Lavori giovanili, in "Opere Complete", I, with an introductory essay by T. Serra, Torino, IBL Libri, 2016, pp. 165, 191, 226, 228.

15 See B. Leoni, Il diritto come pretesa, ed. by A. Masala, Macerata, Liberilibri, 2004; some of these essays, originally published in English, are in B. LEONI, Freedom and the Law, cit..

${ }^{16}$ See C. Menger, Untersuchungen, cit. In this work, and especially in Appendix VIII, "The 'organic' Origin of Law and the Exact Understanding Thereof', Menger - having previously outlined the "organisch" or "unreflectirt" origin of the most important social institutions (see pp. 163-66; Engl. transl. cit., pp. 148-51) - develops his theory on the origin of law and of the opposition between "common law" and "political legislation" (see pp. 271-87), hinting at a solution that seems to derive from Epicureanism, but that may also (as for B. LEONI, see Freedom and the Law, cit., p. 89) find its origins in Roman law. Here, in fact, Leoni, seems to echo the comments of Cato the Censor as reported by Cicero: "the reason why our political system was superior to those of all other countries was this: the political systems of other countries had been created by introducing laws and institutions according to the personal advice of particular individuals like Minos in Crete and Lycurgus in Sparta, while at Athens, where the political system had been changed several times, there were many such persons, like Theseus, Draco, Solon, Cleisthenes, and several others. ... Our state, on the contrary, is not due to the personal creation of one man, but of very many; it has not been founded during the lifetime of any particular individual, but through a series of centuries and generations. For he said that there never was in the world a man so clever as to foresee everything and that even if we could concentrate all brains into the head of one man, it would be impossible for him to provide for everything at one time without having the experience that comes from practice through a long period of history". 


\section{Leoni}

Leoni's objective in the Handouts is to demonstrate the "substantial affinity between the classical statement of the problem of 'law' and the contemporary one". His question is thus linked to the one posed by the Greeks who asked themselves what was the thing which we now called 'positive law', and if, and for what reasons, this "ought to be observed". It is an investigation, therefore, into the nature and position of law within the human sciences. This has both a direct political relevance, since it concerns the "foundation of obligation", and a direct philosophical relevance, because it invites a comparison between the 'laws' of the physical world and the supposed 'laws' that govern the unfolding of historical events ${ }^{18}$.

After establishing as a background the opposition between nomos, physis, and thesis, Leoni moves to demonstrate how among both the Greeks and the moderns, 'positive law' had been presented "as a written norm, formulated in general terms, applicable to all members of a community, and imposed coercively, if needs be, by the dominant political power within that same community". He intends, therefore, to understand the characteristics of the particular type of law which, at a certain point, was called ' $v o ́ \mu \circ \varsigma$ '. He even shows how the concept of vó $\mu$ o $\varsigma$ underwent an evolution and demonstrates that - in an age in which it was understood in relation to religion - it still referred to "the persistence of custom" 19 .

Here he outlines a relationship between religion and law to which he also connected the gradual transformation of the $\theta \dot{\varepsilon} \mu 1 \sigma \tau \varepsilon \varsigma$ (the "decisions of those that resolve disputes": priests, king, or respected men), into a body of decisions, which, while having "the value of precedent" and endowed with "authority that comes from their putative

17 See F.A. HaYeK, The Constitution of Liberty, 1960, now ed. by R. HAMOwy, in "The Collected Works of F.A. Hayek", Chicago, The University of Chicago Press, 2011, pp. 346ff.; F.A. HAYEK, Law, Legislation and Liberty, cit., vol. II, pp. 168-174; and B. LEONI, Il concetto di stato nella teoria kelseniana, (1961), Engl. transl. The Notion of the State in Kelsen's Theory, in B. LEONI, Law, Liberty and the Competitive Market, ed. by C. LotTIERI, with a foreword by R.A. EPSTEIN, New Brunswick-London, Transaction, 2009, pp. 185192, and B. LeOnI, Lezioni di filosofia del diritto e di dottrina dello Stato, cit.

18 B. LeONI, Il pensiero antico, cit., p. 11.

${ }^{19}$ B. LeONI, Il pensiero antico, cit., p. 13. 
divine origin", were not yet backed by "coercive force". With these decisions presented as a corpus, the consequent formation of a customary law valid for all the Greeks came about through the influence of the oracle of Delphi, the centre of religious, political, and juridical life. Leoni observes that subsequent to this, Draco and Solon, ascribing "a greater generality to $\theta \varepsilon \sigma \mu$ ó $\varsigma$ ", made "not only the judges subject to the norms contained in it, but the generality of the citizens" who swore to observe them ${ }^{20}$.

In this way, "while custom, loosening itself gradually from the $\theta \varepsilon \dot{\varepsilon} \mu 1 \sigma \tau \varepsilon \varsigma$ and entering into force little by little, appears the result of collective will, not individuated in time", the $\theta \varepsilon \sigma \mu$ ó transforms itself $^{\prime}$ into "an immediate manifestation of human will", as the "result of an individual legislator" and, with Peisistratos, it headed towards first "becoming vó $\iota^{\prime} \zeta$ ", and then transformed itself "into imperative law". It was thus in the sixth century that "the prevalence of the coercive element of the laws through civil struggles and tyrannies" finished by

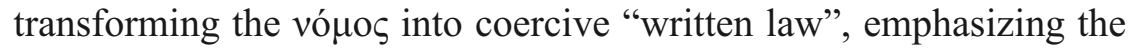
distinction between this "and çง $\zeta$, that is, custom and usage" 21.

Having dealt with the relationship between 'juridical law' ("a complex of written norms, binding, endowed with general validity, furnished with sanctions brought into being by a political power") and "physical law' in the sense of a "religious conception of nature" and then later of the transition to "physical science in the modern sense", Leoni confronts the problem of the "latent and sometimes explicit antithesis between necessity and rationality in the "laws of nature". He concludes that the Greeks had elaborated "on the one hand a conception of physical law as an unavoidable necessity resulting from phenomena occurring according to a principle of rationality", and on the other hand "a conceptualization of juridical law as a rigid and coercive expression, albeit transitory and subject to change, of the dominant will in the political sphere" 22 .

In this context, there arose in the fifth century "and assumed a multiplicity of aspects, the opposition between vó $\mu$ ○ and $\varphi v ́ \sigma ı$ ". In the context of this opposition, the vó $\mu$ o ended up losing its meaning

20 B. LEONI, Il pensiero antico, cit., p. 18.

${ }^{21}$ B. LEONI, Il pensiero antico, cit., pp. 19-21.

22 B. LeONI, Il pensiero antico, cit., pp. 21-23. 
of "written law, coercively [imposed on everyone] by means of political power" and assumed the meaning of "custom". It was in this way that it was used by Herodotus, Aristophanes, Thucydides, Plato and Aristotle, not only to designate "the rules of rhythms, of poetic meters, and of language" but even "tradition and custom" and, with Heraclitus, as that thing that "was made by men for themselves" in opposition to

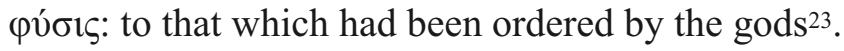

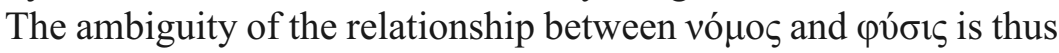
at one with the ambiguity of the term 'nature', a term which Leoni understands as the "natural impulses that law and custom seek to moderate between them, in other words the "effective constitution" of men, independent of "artificial social conditions", as well as "their original condition of 'equality (real or imagined)', predating and opposed to every distinction of historically determined laws and customs". And if for Archelaus

"vó $\mu$ o $\zeta$ is that which is connected and in some way depends on human will (manifesting itself in the form of opinion, habit, convention, custom, technical rule, written law), [while] púøıৎ is that which we find, as with the Homeric Moira, beyond the human world, since it is beyond the scope of human will: $[\ldots]$ binding, that which human convention can downplay but not suppress, and to which it is inevitably bound to bend itself or unify itself",

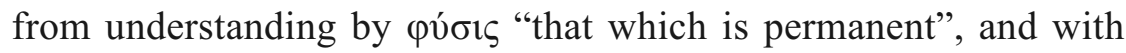
vó $\mu$ ○ `"that which changes and alters itself", the Greeks were drawing "increasingly various and at times contradictory conclusions" about "if, and why, [...] one should have to obey [the vómos]"24.

This process finished by manifesting itself in an opposition between those who were looking to justify obedience to the vó looking for reasons to oppose it and those who maintained that the vóno s "did not need to be compared with nature" to be justified: among the former group Leoni placed Thrasymachus and Carneades, and among the latter he placed Pericles (the father of Athenian democracy), who maintained (as we read in the dialogue with Alcibiades as recounted by Xenophon in the Memorabilia) that "the law is all that

${ }^{23}$ B. LEONI, Il pensiero antico, cit., p. 36.

24 B. LeONI, Il pensiero antico, cit., pp. 38-39. 
the people in assembly decide and lay down in writing, that which should be done, and that which should not be done". For Leoni, this pronouncement represents "the departure point of criticism of the vó $\mu$ c $\zeta$ " understood as "written law sustained by coercion exercised by the dominant political power", an idea that, together with Protagoras's justification of the "law as an expression of the will of those who, having created it, must observe it", would exert a considerable influence, and that can be understood as the juridical presupposition of that democratic regime to which even Socrates yielded 25.

In short, Leoni shows how modern theories of democracy derive from a correlation instituted by the Greeks of the classical era between democracy and legislation which is understood as the written law produced and applied imperatively by a political power.

It is thus understandable why the attempt to reconcile vó $\mu$ ○ $\varsigma$ and pv́бıৎ that would be developed in Aristotle and would pass from the Stoics, via Cicero above all, to the Apologists, the Christian Doctors and Church Fathers, as well as to many philosophers of Natural Law, should appear of less interest to Leoni than the theories of those (Hippias, Sophocles, Euripides, Alcidamas, Callicles, and Thrasymachus) who "by means of the noted Law-Nature antithesis" denied the obligatory nature of the vó $\mu \varsigma^{26}$.

Indeed, from Plato's attitude “towards the noted vó $\mu$ o $-\varphi v ́ \sigma ı \varsigma$ antithesis", Leoni drew the conclusion that Plato's principal interest did not consist "in an interpretation of the law of the State as an object of historical experience, but in the superimposing of a model over this experience". His aim would in fact be to reform all knowledge on the foundation of a science "accessible to very few, not drawing on historical experience, but rather from a long and grueling exercise of reason". Taking up once more the Socratic program, Plato would have thus subjected everything, including right, the laws, and the politeia,

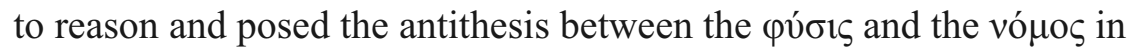
a more radical way: as the antithesis between the rules of the sciences that have nature as their object (the 'laws' of the natural sciences) and juridical laws. Interpreting "the politico-juridical in the same way as

25 B. LeONI, Il pensiero antico, cit., p. $46 \mathrm{ff}$..

${ }^{26}$ B. LeONI, Il pensiero antico, cit., p. 54ff.. 
the physical world", he would have also overcome the "formalist theory of law" that Pericles had devised, with an explanation that, "as is the case today", Leoni saw founded

"on certain notes or different characteristics of the vó $\mu$ os, namely coerciveness, general applicability, derivation from a 'formal' source which is identified in the legislative power of the State [and in which] the very concept of juridical law $[\ldots]$ dissolves itself $[\ldots]$ before the truth of 'science' which appears from the results of one who, having acquired this truth, must use it for human society"27.

This definition was understandable because "many have seen in Plato one of the most rigid proponents of Natural Right, understood as that which is rationally just and useful" and because his work "is the reverse of modern thought, which considers juridical norms as something eminently relative to a certain time and historicallydetermined society".

The problematic "relationship between positive law and natural or rational law" was, however, taken up again by Aristotle who made an attempt to reconcile them. Leoni seems to have been more than anything else interested in his 'theory of justice' and particularly in the search for "an objective basis (that is, independent, within certain limits, of the intentions and agreements of the subjects of the relationship)" starting with "need". This was seen

"as the very foundation of the juridical community: 'there would not be community', he writes, [...] - if there were not exchange, nor exchange if there were not equality, nor equality if there were not commensurability. Logically and in a true sense it would be impossible that things so different from one another should be commensurate, but thanks to need they most certainly can be".

With the reduction of the "theory of particular justice to the theory of economic need, a true and novel theory of Natural Right" had been espoused. Indeed, Leoni deduced from the view according to which "that which is not equal $[\ldots]$ is against nature $[\ldots]$ and that that is

${ }^{27}$ B. LEONI, Il pensiero antico, cit., p. $75 \mathrm{ff}$. . 
against nature is not good", and thus from an understanding of equality as "something profoundly natural" which, in human communities, can be said to be founded on 'the commensurability of goods created by need', that for Aristotle, need stands at the root of all juridical relationships, particularly as the 'natural' element of the law of obligation. Set in opposition to this is money, the conventional way to express need (and it is for this reason in fact that it is called vó $\mu 1 \sigma \mu \alpha$

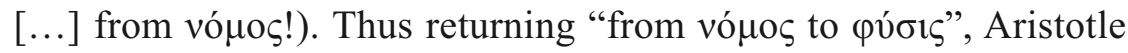
manages to "reconcile the agreed and natural elements in positive legislation" and to thus establish a doctrine of natural right in which "the stable and natural element of law (in particular the law of obligations) is grounded in economic need, a condition in which all men find themselves equal". For these reasons, and notwithstanding the fact that Aristotle was "convinced of the profound difference that exists between men" and was proponent of "natural inequality", the Aristotelian solution constitutes for Leoni the model of "every attempt to conceive of equality and justice in a material sense, or to adapt [...] legal theory to economic theory, which is, in the final analysis, a unique attempt to return from 'agreement' to 'nature'". This was a speculative attempt to understand positive law "as provided by historical experience [which] tends to reconcile to a certain extent the

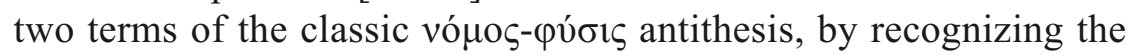
naturalness, i.e. the necessity, and at the same time the rationality of the vó $\mu$ o $" 28$.

Alongside these reflections of Plato and Aristotle, Leoni comments upon the ideas of the Cynics. The Cynics, denying "every rational justification and necessary basis" of the vó $\mu$ os, emphasize the classic

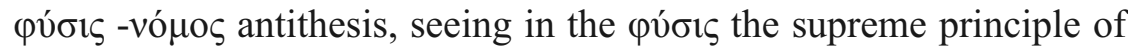
reality to which the works of men must conform. In the struggle "against the vómos understood as the law of social relations", Leoni recognized the anti-political character of the Cynics' doctrine, which, focusing by contrast on "the individual, isolated from the community, ends up subverting the traditional Hellenic world view (manifest in the thought of Socrates no less than in that of Plato and Aristotle) according to which the community holds an ethical value superior to that of any

${ }^{28}$ B. LeONI, Il pensiero antico, cit., p. $113 \mathrm{ff}$. . 
individual". The most interesting aspect of the Cynics' doctrine was therefore "the power attributed to human will to subtract oneself from the vó $\mu$ o $\varsigma$ in order to reconcile oneself to a natural order that the vó $\mu$ o fails to recognize" and in its characterization of $\varphi v ́ \sigma i \varsigma$ as "irreducibly independent of human decisions", "incompatible with the vó os $_{\text {in }}$ as much as $[\ldots]$ the vó $\mu$ o $\varsigma$ was an irrational expression of the beliefs and will of human communities". It was not, however, incompatible "with the efforts and will of the wise man aiming to reach absolute independence from the traditional vó ${ }^{\circ} \varsigma$ " who adjusted himself "to the rationality and higher necessity of nature" and repudiated "that which is opposed to it" 29 .

The belief that "nature constitutes a homogenous unity, dominated by rational and binding laws" thanks to a "divine necessity that dominates the world" and that nature is an environment in which "the individual human soul is no more than a part" which must adapt itself "to the necessity and deep rationality of the world", was taken up and consolidated by the Stoics who outlined a view that in turn would give rise to Epicureanism ${ }^{30}$.

The protagonist of the Stoic "life according to nature", the seeker of happiness ("the supreme aim of moral activity") who frees himself from everything that is "foreign to his own will and reason", is the wise person: "the individual who is entirely self-sufficient and who conquers happiness completely on his own". Here the ancient "Hellenic ideal of the polis" undergoes a drastic transformation that manifests itself in a semantic shift: "the law that dominates the world" is referred to using the same term "traditionally given by the Greeks to human laws: it is called vó $\varsigma^{\circ}$ ". For Leoni, this shift demonstrates the Stoic conviction "that the rationality of the world does not suffer exceptions even in the ethico-political realm and that there is no nomos worthy of the name which does not mirror Natural Right" and does not adapt itself to it. Leoni also sees this idea being expressed - above all with Diogenes Laërtius and with Stobaeus - in "the antithesis between that which is established by men in existing historical laws, and that which is just

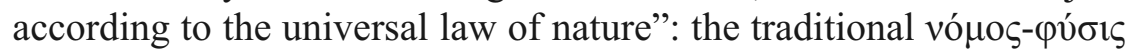

${ }^{29}$ B. LEONI, Il pensiero antico, cit., p. 122.

${ }^{30}$ B. LEONI, Il pensiero antico, cit., p. $125 \mathrm{ff}$. 


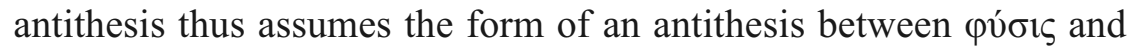
$\theta \dot{\varepsilon} \sigma 1 \zeta^{31}$.

It is at this point of the evolution of this antithesis that Leoni turns his attention to Epicureanism in which

"the attempt to reconcile the classic antithesis is posed in a different way, creating a doctrine that would reveal itself of exceptional importance for the development of ideas about law and the State in the modern era: the doctrine of contract as the foundation of political communities and of legislation in general" 32 .

Without any reference to Lucretius, Leoni recognizes that it is difficult to reconstruct the origins of Epicureanism given that the relevant works remain fragmentary, and that Epicurus was probably "a continuator and transmitter of doctrines" among which he counted Democritus's "explanation of the origin of human society based on the agreement of individuals", an idea which, in turn, can be traced back to the theory "of the consensual origin of language". "Epicurus [was] not the founder of the doctrine of contract", and there were good reasons to think that these ideas had already gained wide currency by Aristotle's time. On this point, Leoni reports that a) Critias maintains that "originally men lived without laws or rules, like animals, and only later, to protect themselves against violence, did they create penal laws: then, seeing as how these were only able to affect external action and not internal feeling, a wise person thus invented the gods, that see and punish even hidden wrongs"; $b$ ) that "some interesting contractual interpretations of law and of the historical State can be already found in the work of Plato", attributed to Callicles and to Glaucon, and c) that "the very practice of legislation in the democratic $\pi$ ó $\lambda \varepsilon 1 \zeta$ of the fifth century" was rendering the doctrine of contract natural because "every citizen of those $\pi$ ó $\lambda \varepsilon 1 \zeta$ was able to assist in the birth of each law by means of the agreement of all citizens that enjoyed political rights" 33 .

For Leoni, the innovation represented by Epicureanism therefore resides in its 'transferring the problem of 'legality' from the realm of

${ }^{31}$ B. LEONI, Il pensiero antico, cit., pp. 125-128.

32 B. LEONI, Il pensiero antico, cit., p. 129. (my italics).

33 B. LeONI, Il pensiero antico, cit., p. $131 \mathrm{ff}$. 
the democratic $\pi$ ó $\lambda \varepsilon 1 \varsigma$ to the realm of legislation in general", restoring "the source and the very substance of all the laws" to an "agreement between participants of whatever historical society". This was a radical transformation that, unfortunately, had given rise to "discordant interpretations" on account of its being expressed in a series of brief maxims which were of "epigraphical" and "fragmentary" nature, and thanks also to a lack of comparison with themes elucidated in other writings attributed to Epicurus. Leoni lingers on the Rata Sententia XXXI ("The justice of nature is a pledge of reciprocal usefulness, [i.e., ] neither to harm one another nor be harmed"), making it clear that on its interpretation "depends the interpretation of the entire Epicurean doctrine of contract". Here we find

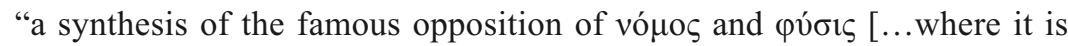
affirmed] that the law is the direct product of agreement (contract), but that men naturally or rather necessarily agree this reciprocal contract in order to keep themselves alive. In the final analysis, the juridical and political life of human communities thus has its basis in nature, seeing as how the contract that stands at its origins has as its cause the natural utility of the contracting parties. Through this maxim [...] emerges Epicurus's concern to maintain an indissoluble connection between the two concepts of usefulness (natural element) and of pact (arbitrary, agreed element) for defining the right: when either of these elements is missing, the concept of justice fails. It is possible to have unjust agreements on account of their being useless as well as relationships between beings which are not tied to any pact: relationships which are useful in practice, but that cannot be called 'just' because of the absence of that agreed element which is intrinsic to the concept of justice" 34 .

On this basis, Leoni holds that the Epicurean theory of the origin of language has "a perfect correspondence" with that of the origin of law as contained in the few works which remain extant:

"Hence, names too did not originally come into being by convention, but by the very natures of men, who undergo particular feelings and receive particular presentations according to the tribes they live in, expelled air in particular ways as determined by each of their feelings and presentations ... And later [the names] were established by a general convention in each tribe,

${ }^{34}$ B. LeONI, Il pensiero antico, cit., pp. 134-137. 
in order that their meanings might be less ambiguous for each other and might be expressed more succinctly" 35 .

\section{Leoni thus sees Epicurus challenging the opinion which holds that}

"not even the vó $\mu$ o can be transgressed with impunity, for the anxiety that the transgression inevitably causes in the transgressor: this amounts to maintaining that obedience to the law always has a natural foundation, in as much as it is founded on fear of the reaction of all those who, obeying a requirement of utility, introduced the same law by means of contract"36.

\section{In particular, Leoni dwells on the final three Ratae Sententiae ${ }^{37}$ in}

35 EpICURUs, Letter to Herodotus, 75-76 (DIOGENEs LaËRTIUs, X, 75-76); the English translation used here is taken from The Epicurus Reader, Selected Writings and Testimonia, translated and edited, with Notes, by B. Inwood and L. P. Gerson. Introduction by D. S. Hutchinson, Indianapolis-Cambridge, Hackett Publishing Company, Inc. 1994, p. 16. In the original, Leoni uses the translation of E. BIGNONE, Epicuro. Opere, frammenti, testimonianze sulla vita, Bari, Laterza, 1920, pp. 106-107.

36 B. LeONI, Il pensiero antico, cit., pp. 138-139.

${ }^{37}$ Curiously, perhaps thanks to influence of the aforementioned Aristotelian theory of exchange arising from need, Leoni here does not seem to apprehend the profound innovation represented by Ratae sent., XXXII: "There was no justice or injustice with respect to all those animals which were unable to make pacts about neither harming one another nor being harmed. Similarly, [there was no justice or injustice] for all those nations which were unable or unwilling to make pacts about neither harming one another nor being harmed"); XXXIII: "Justice was not a thing in its own right, but [exists] in mutual dealings in whatever places there [is] a pact about neither harming one another nor being harmed"; XXXIV: "Injustice is not a bad thing in its own right, but [only] because of the fear produced by the suspicion that one will not escape the notice of those assigned to punish such actions"; XXXV: "It is impossible for someone who secretly does something which men agreed [not to do] in order to avoid harming one another or being harmed to be confident that he will escape detection, even if in current circumstances he escapes detection ten thousand times. For until his death it will be uncertain whether he will continue to escape detection"; or, finally, XXXVI: "In general outline, justice is the same for everyone; for it was something useful in mutual associations. But with respect to the peculiarities of a region or of other [relevant] causes, it does not follow that the same thing is just for everyone". Regarding the Ratae sent. mentioned, Leoni, having mentioned the doubts of P. Gassendi and F. Usener on their origins, embraces implicitly the contrary thesis of "our Bignone", referring to DiogEnES LAËRTIUS, X, 150ff. The English translation used here is taken from The Epicurus Reader, cit., pp. 35-37. The Italian translation used by Leoni, except that of Ratae sent. XXXI and XXXXII, is that of E. Bignone, Epicuro, cit., pp. 55-69. In the Ratae sent. mentioned by Leoni, the possibility seems to be raised that not all contracts (or exchanges) are concluded, that these serve to reduce 'ambiguity' and 
which a polemic is outlined "against those who [...] denied the natural character of positive law" on account of its "transitoriness and changeability". His interest in "juridical Epicureanism" thus seems motivated by its maintaining that "justice and legality in a formal sense [are not] identical terms: it is precisely utility that confers the blessing of justice on those laws deliberated upon in any political community". This is almost an anticipation of the criticisms that would be levelled at proponents of the idea that "the laws of a city are just in so far as the city itself decrees them and so long as that it considers them in force, independent of the benefit that those same laws bring to the city". The Epicurean theory is thus a juridical theory that aims "to make the justice of the laws (i.e. their derivation from the legislative power of the city) coincide with their usefulness" 38 .

It was this, in its entirety, which would be the original relevance of the Epicurean theory of contract, a theory which does not trouble itself with politics but only asks "what is the foundation of justice", not saying anything "of the juridical nature of contract" and "remaining silent" on the questions of "who the contracting parties are, the clauses and conditions of the contract, and their scope and force". Epicurus thus appears

"uniquely, [as] a philosopher that deals with social ethics. The social contract is therefore only a metaphor loaned from juridical language that should not be taken literally. It is a contract of assurance and mutual security with which we specify that which is right and that which is not. Justice rests on acceptance of the law, and this acceptance is given by means of contract".

And yet, as much this doctrine of contract appears indifferent to the question of 'good political order', it nevertheless "even in its abstraction and imprecision must have constituted throughout medieval and, above all, modern though, the departure point for a series of

time; that justice and injustice do not exist in and of themselves but only on the basis of contracts and that no behaviour contrary to the contract can be carried on for any length of time without it being sanctioned in some way. These are all anticipations of the decidedly innovative theories that re-echo in the words with which B. LEONI, in 1950, in Our Mission, presents the first edition of "Il Politico" and that seem to have left traces (never acknowledged) in the entirety of Leoni's theory of law.

${ }^{38}$ B. LEONI, Il pensiero antico, cit., pp. 139-140. 
exceptionally fruitful developments" 39 : a development that, unfortunately, Leoni would not elaborate upon in his subsequent works, and which in this work would only be traced up to the juridical doctrine of the Romans and first Christians.

Leoni thus left unanswered a question which, in these same years, Strauss had posed when writing of the relationship between atheism and political hedonism in Natural Right and History. Whilst referring to the same thinkers mentioned by Leoni, he spoke of the link between "the creator of political hedonism", Hobbes, and Epicureanism, or rather that which, as mentioned, "revolutionized human life everywhere on a scale never yet approached by any other teaching" 40 : in short, of the complex birth of modernity and of 'true and false Individualism'.

\section{Menger}

Before moving on to examine what Hayek could have drawn from Leoni with respect to the opposition between physis, cosmos, taxis, and nomos, we should briefly make reference to Menger, precisely because Hayek refers primarily to Menger ${ }^{41}$ when he deals with the origin of social institutions and takes his theme and inspiration from his work. Menger, while known as an economist, elaborated a resolution of the antithesis which in modern terminology could be defined as the opposition between 'common law' and 'legislation'.

We cannot make more than a reference, at this point to a potential comparison between the Epicurean theory of the satisfaction of 'desires' and the Mengerian theory of 'needs', nor to the 'subjective function of utility' as a source of the value of goods and to Epicurus and Menger's

${ }^{39}$ B. LEONI, Il pensiero antico, cit., pp. 140-141.

${ }^{40}$ L. Strauss, Natural Right and History, cit., p. 169. On this question, see R. Cubeddu, L'Epicureismo nell'opera di Leo Strauss, in "Philosophy Kitchen", VII, marzo 2020, pp. 133-62.

${ }^{41}$ While the references to Menger in Hayek's work are many and positive, and Menger is placed, alongside Mandeville and Hume, among the thinkers with whom he feels a particular affinity (see F.A. HAYEK, Kinds of Rationalism, in F.A. HAYEK, "Studies in Philosophy, Politics and Economics", London, Routledge, 1967, p. 84), references in Leoni are very rare and do not lead one to think that he had knowledge of his theory of right as an "exchange of powers". 
criteria for their valuation and classification. We must content ourselves here with observing how, from this perspective, the Mengerian solution shares characteristics with the (never referenced) Epicurean one, even with regards to the origin of social institutions, starting with language, which are seen as unintended consequences of 'exchange' and of 'pacts'. In short, it can be said that for both theories, every human action, whatever its motivation and ends (including the unavoidable fulfilment of natural and necessary needs and desires), has some unintended consequences.

The genesis of the "most important social institutions" which arose in an unintentional manner ["auf unreflectirtem (auf organischem) Wege"], is outlined by Menger in the Untersuchungen über die Methode der Socialwissenschaften, in which he writes:

1) that "there are a number of social phenomena which are products of the agreement of members of society or of positive legislation, the results of the purposeful common activity of society thought of as separate active subjects", and that in these cases one can talk of a "pragmatic" interpretation of these phenomenon and that the essence and origin of them can be explained "from the intentions, opinions, and available instrumentalities of human social unions of their rulers";

2) that alongside this typology of phenomena and social institutions exists another - which is also the more important - according to which such social institutions are not

"the result of agreement of members of society or of legislation, as we have already explained. Language, religion, law, even the state itself, [...] markets, competition, money, and numerous other social structures are already met with in epochs of history where we cannot properly speak of a purposeful activity of the community as such directed at establishing them. Nor can we speak of such activity on the part of the rulers. We are confronted here with the appearance of social institutions which to a high degree serve the welfare of society. Indeed, they are not infrequently of vital significance for the latter and yet are not the result of communal social activity. It is here that we meet a noteworthy, perhaps the most noteworthy, problem of the social sciences: How can it be that institutions which serve the common welfare and are extremely significant for its development come into being without a common will [Gemeinwillen] directed toward establishing them? [...] All these social structures in their various empirical forms and in their constant change are to a no small extent the unintended result of social development". 
So much so that it can be affirmed that "the solution of the most important problems of the theoretical social sciences in general and of the theoretical economics in particular is thus closely connected with the question of theoretically understanding the origin and change of 'organically' created social structures"42;

3) that "the opinion ascribed to Aristotle that the state is an original phenomenon given simultaneously with the existence of man" from which is taken the celebrated Aristotelian motto anthropos zoon politikon,

"does not mean that man has always lived in a state and that the latter is as old as man himself. It means only that the instincts inherent in man impel him toward associating with others and toward forming a state and that man in the 'Greek' sense, civilized man, cannot be older than the state [also because, as is clear from] common sense, [...] a complicated whole cannot be just as old as the elements to which it necessarily owes its existence"43.

The birth of law is examined in Appendix VIII: "The 'Organic' Origin of Law and the Exact Understanding Thereof'. Here Menger writes that

"Law as the intended result of the will of an organized national community or of its rulers is a phenomenon which does not challenge the sagacity of the scholar unduly either in respect to its general nature or its origin. But the case is different with law wherever it appears not as the result of positive legislation (of the intended common will), but as the result of an 'organic process"'.

\section{In many cases}

"we are met with a social structure which in the most outstanding sense benefits the common welfare. Indeed, it really conditions it and yet does not appear as the result of a will of society directed toward this. An unintended product of social development which conditions and advances the welfare of society, and this perhaps to a higher degree than any social institution which is the work of human intention and calculation - the explanation of this remarkable phenomenon is the difficult problem which social science has to solve".

\footnotetext{
42 Menger, Untersuchungen, cit., pp. 161-66; Engl. trans. cit., pp. 145-47.

${ }^{43}$ MeNGER, Untersuchungen, cit., pp. 267-70; Engl. trans. cit., pp. 220-22.
} 
Having discarded the "reflexive (pragmatic)" solution and the solution which bases itself on an analogy "between the genesis of natural organisms and that of law", Menger turns to study nature and "the course of the process by which law appears without positive legislation". He observes, first of all, how the "law came into being in periods of human development which are far before those of documented history", how it "actually developed originally in individual concrete cases" and how it should be studied with respect to "tendencies of general human nature" and to the "external conditions" that have characterized its "particular empirical forms". That which interests Menger is thus the development of articulated and complex juridical forms arising out of their most simple forms; from that "external situation" - and here we could be hearing an echo of Lucretius's theory on the origin of society ${ }^{44}$ or, more likely, the influence of 'romanistic doctrine' -

"in which family heads of a territory find themselves under the most primitive conditions plus the insecurity, common to all, of the products of their individual efforts, [which] cause the oppression of the individual to be felt most keenly by all others, too. It is human nature to feel the continued threat of evils almost more acutely than the threatened evils themselves. Each individual, even if not directly harmed, feels threatened most seriously in his interests by acts of violence, especially to a weak individual, who is always in the majority compared to the strong one".

On this point, Menger observes that, as much as in its current forms law is above all of legislative origin and for this reason is interpreted "in a pragmatic manner, through the intentions of the lawgivers and the conditions determining these", even this situation is the result, perhaps the unintentional result, of an evolutionary process that cannot be initiated by any individual or collective act of will consciously directed to the formation of law: the conditions for consenting to it were lacking 45 .

${ }^{44}$ Undoubtedly the Mengerian thesis on the origin of the most important social institutions is analogous to the Epicurean-Lucretian thesis, but Menger never mentions Epicurus or Lucretius and did not even own a copy of their works. It thus seems to be the result of a spontaneous convergence.

${ }^{45}$ C. MENGER, Untersuchungen, cit., pp. 270-73; Engl. trans. cit., pp. 223-25. It should 
It is this very thing which gives rise to "the conviction of the necessity of...limits of despotism", a conviction that is born and spreads "in the minds of individual members of the population with the increasing awareness of their interest, the individual interest. What benefits all, or at least the far great majority, gradually is realized by all"; "rules for action" follow, formed from reflecting on "their welfare" and on "his interest" that "becomes the interest of every individual" and the knowledge that his protection is a part of the interests of every individual. "There thus develops in the population the awareness that adherence to rules in the concrete case is not at the discretion of the individual, but must be assured" 46 .

In this way, alongside the "contrast between law and morals", Menger also see the original "concept of national law" ["der Begriff des Volksrechtes"] emerging: he considers the use of force foreign to that concept, even as a means of policing transgressions. This means that, in its original form, "law [...] arises and lives only in the mind of the population, but its realization is also exclusively the affair of the latter" and, being part of "external destinies, through the community of history" of "kinship", of "language", "religious feelings" and "convictions pertaining to the law" generates gradually among the people "the idea of a closer solidarity, the awareness of national community, and an organization bringing together all people of the nation into a higher unity"47.

Menger ${ }^{48}$ maintains that it is only at this point that law, "which up

be noted that we find ourselves before a restatement of the Epicurean thesis where a situation of uncertainty between neighbours was at the origin of pacts (Ratae sent. XXXIIXXXVIII, and above all LuCRETIUs, De rerum natura, V, 1011-27). Through these pacts - which, as in the case of Mengerian exchanges, can take place, but do not necessarily do so - neighbours procure reciprocal advantages, and on account of "the continued threat of evils [felt] almost more acutely than the threatened evils themselves", there is a general utility, which nevertheless has to be demonstrated, to observe such rules.

${ }^{46}$ C. Menger, Untersuchungen, cit., pp. 273-75; Engl. trans. cit., pp. 225-26.

${ }^{47}$ C. Menger, Untersuchungen, cit., pp. 275-77; Engl. trans. cit., pp. 226-27.

48 It can be said that Menger pertains to that group of thinkers who, consciously or not, project the Epicurean theory of the birth of institutions into an associative dimension different from that of the 'Garden', which seems rather to derive from a 'secession' from 'civil society' which in turn could have had an origin analogous to that outlined by Epicurean theory. In effect, we do not know how the 'Garden' was born and one can conclude that, unlike the Lucretian societas, its origin is voluntary and not 'unintentional'. 
to then was alive only in the minds of individuals [... and] found its guarantee in the energy of individuals [...] becomes the expression of the uniformly organized national will": a state. Law is thus "not the result of a contract or [...] reflection aiming at the assurance of the common welfare" and is not even, as the Historical School of Law believed, "given with the nation". It is, rather, "older than the appearance of the latter. Indeed, it is one of the strongest ties by which the population of a territory becomes a nation and achieves state organization". This is a transformation of law that appears gradually and that, before legislation forges law into a particular shape, originates from a guarantee "of the most important and most general interests of the people". From here "it broadens and deepens gradually with increasing intercourse and the growing insight of individuals into their interests. It is affirmed by custom and is shaken and finally altered by the change of those conditions to which it owes its origin"49.

Standing in opposition to this way in which law is created and evolves, Menger sees another that emerges as an effect of the authority that powerful or intellectually superior men exercise over the weakest, imposing set behaviours, limits, and prescriptions: in short, an obedience that bases itself on fear, not on utility. These, rather than Law or Right [Recht], ought properly to be called statute or legislation [Gesetz], even if he who produces it has "a strong interest" to call it law, and to attribute to it "the sanctity of law", in "connecting [it] with religious tradition", to elevate it to an object "of religious and ethical education" to produce obedience, submission and to elide the distinction between "rules limiting the discretion of the individuals

${ }^{49}$ See C. Menger, Untersuchungen, cit., pp. 277-279; Engl. trans. cit., pp. 227-228. It should be noted in this case that Menger dismisses the idea of contract as a common pact that binds everyone for the achievement of a single goal (a thing that the Epicurean juridical doctrine would not at any rate have contemplated because it would be tantamount to a 'political contract') but affirms that Law, which is neither 'eternal' or 'original' and not even of divine origin, 'serves' human interests and is the irreflexive result of a 'human intelligence' that derives utility from it for its own individual ends. A community can arise from this that nevertheless identifies itself with a respect of rules which are held by everyone and useful to all. The presence in Menger of another Epicurean theme should also be noted, whereby the law, established by means of custom and not yet by political imposition, is disrupted, and is eventually transformed or abandoned because it is no longer useful, on account of a change in the conditions to which it owes its origin (see Ratae sent. XXXVIII). 
which are produced by $[\ldots]$ conviction $[\ldots]$ from those which power prescribes for the weak". Here Menger clearly perceives a difference between Law or Right (which bases itself on reciprocal usefulness) and Statute or Legislation (which bases itself on fear), recognizes this as a factual reality, and also notes - taking up another Epicurean theme, namely the negative effects of religion and of the political usefulness of the fear it creates - how fear of the law, "connected with religious tradition", can be used to produce submission ${ }^{50}$.

That Menger did not have particular sympathy for this form of statute becomes clearer in a note, in which he substantially denies, as Epicurean doctrine does, the pre-existence of Right or Law (natural or revealed) in human society. He in fact specifies that, as much as "legal order is a condition of all relatively progressive intercourse; the latter in turn is a condition of all higher human welfare, [and] the desire for welfare $[\ldots]$ is in general human nature, the law is not a change affair", "implicitly given essentially by human nature and the particularity of conditions". In consequence

"law is not already something real either in terms of idea or particular content [but must be] created by a mental process. [...] It is the task of science to give us clarity concerning this process, a task which is by no means solved by the phrases 'originality', 'primeval nature' or 'organic origin'. By attacking the solution of the above problem relevantly, we have at the same time shown that law in its objective reality is not contained a priori in the human mind in general or in the national mind in particular, nor is it revealed by an intelligence external to the human race. Rather, as far as it is presented to us not as a product of power or of positive legislation, it is the result of reflective consideration and judgment of needy human nature and the conditions that environ the members of a nation. Law is thus not an end in itself. It is so definitely not this that it would disappear at once and become just a useless and burdensome limitation of human freedom if those barriers to individual discretion which we call the legal order were to become superfluous in a certain state of society, or if law were to become detrimental to human welfare".

Thus, as with Epicureanism, the law is the result of a reflection on human nature, on the coinciding of individual and general usefulness,

${ }^{50}$ See C. Menger, Untersuchungen, cit., pp. 279-281; Engl. trans. cit., pp. 229-230. 
and on the natural environment, which tends to guarantee conditions of individual well-being: if these conditions change without the Law adapting itself in turn, it can become harmful to the "common good'. Far from being "external", "native to human breast", or "divine", it is therefore "an institution sprung from human intelligence and serving human interests" and is not "the result of an (intended) common will directed toward establishing it and toward the furthering of human well-being. Originally it was not this at all. This is a fact which, however, by no means excludes the genesis of law as a result of human intelligence" 51 .

Alongside the errors of those politicians that thought to "act for the common good" by means of "theoretical one-sidedness and erroneous desire for innovation" and who favour it with positive legislation that often works for particular interests and not for social usefulness, Menger draws attention to the jurist class and the rulers, and maintains that "the jurists joined hands to replace the common law [Gewohnheitsrecht] which arose from the nation [Volk] and for the nation [Volk] with one which was to serve the rulers!". In this way, the merits of the Historical School of Law, in marginalising "those immature and precipitate reform efforts in the field of legislation" and in promoting the study and comprehension of law, are served with a 'reproach' for their failure "to make us understand theoretically the nature and the course of that process, the result of which is common law". In this way, the return to the "higher wisdom" of the common law avoids an adequate scientific explanation of the process by which the "common law has also proved harmful to the common good often enough, and, conversely, legislation has just as often changed common law in a way benefitting the common good" 52 .

While demonstrating the real propensity for synergy between common law and legislation, Menger observes that in the battle that had been waged against this latter category, it had been forgotten that "common law is, indeed, the result of the common will aimed at the common good but [... is] an outcome of individual human efforts, and

${ }^{51}$ C. Menger, Untersuchungen, cit., pp. 282 ff.; Engl. trans. cit., pp. $231 \mathrm{ff}$. It should be noted how for Menger, unlike Hayek, law is 'created' (intentionally and/or unintentionally) and not 'discovered' by man.

52 C. Menger, Untersuchungen, cit., pp. 280-285; Engl. trans. cit., pp. 230-233. 
thus not in direct contrast to human wisdom". This means that it is possible to intervene in that process and that such an intervention on the part of the "statesman" or wise person becomes needful whenever we find ourselves confronted with harmful phenomena ${ }^{53}$.

These Mengerian reflections contrast with what we find in Epicurean legal theory, in which a political dimension and a political projection of law are missing and are in fact consciously excluded. Here we reach the limits of Menger's concurrence with Epicurean doctrine on the origins and functions of law, for Menger's conclusion is that the role of the jurist, which inspired the ideas of the Historical School of Burke and Savigny, should not be limited to proclaiming "the 'higher wisdom' of common law', but that the jurist ought rather to put his knowledge at the disposition of the legislator, thus encouraging constant adaptation to a changing situation. This assistance would be able to forestall both "immature or hasty reforms" and prevent renunciation of reform based on a "refrain from any interference in the development of this organism" due to a "veneration for the high wisdom which is manifest in nature ... are there not even absolutely noxious organisms?" Therefore

"as the farmer, the technologist, and the physician investigate nature and the laws of its motion in order to shape things for their purposes on the basis of the thus gained insight, so, too, the historical school of jurists had to make us understand the previously uncomprehended advantages of common law. They had to do this to offer to the lawgiver new ways and means to practice his high profession through the thus expanded knowledge. But never, and this is the essential point in the matter under review, may science dispense with testing for their suitability those institutions which have come about 'organically'. It must, when careful investigation so requires, change and better them according to the measure of scientific insight and the practical experience at hand. No era may renounce this 'calling'["Beruf"]"54.

We will return later to the problem of when and how to intervene when it becomes clear that those institutions which have arisen in an

${ }^{53}$ C. Menger, Untersuchungen, cit., pp. 285-286; Engl. trans. cit., p. 233. An analogous idea is outlined in Ratae sent. XXXVIII.

${ }^{54}$ C. MENGER, Untersuchungen, cit., pp. 286-87; Engl. trans. cit., pp. 233-34. 
"organic-unintended" manner (or rather those institutions that, on account of the process of their genesis, incorporate more abstract and practical knowledge) to serve the realisation of individual welfare and 'common good', become insufficient and harmful with respect to new and unexpected circumstances.

\section{Hayek}

Even if Leoni writes of the origin of law and of the opposition between jurisprudential law and legislation in other works, in particular in Freedom and the Law, that which interests us here is if his distinction between physis and nomos influenced what Hayek writes in Rules and Order.

Having outlined the origins of the 'constructivist rationalism' [of Descartes and Hobbes] in the primitive propensity "to interpret all regularity to be found in phenomena anthropomorphically, as the result of the design of a thinking mind", Hayek (without mentioning Lucretius) observes that another approach stands in contrast to this one. This approach interprets social institutions that increase the "effectiveness of individual action" not as the result of an invention of an individual or social capacity for design but largely as the unintentional outcome of an evolutionary process. Dwelling on the errors of the first approach, Hayek underlines its disregard for tradition and customs, and the conviction (which Leoni had attributed to Plato) that society ought to be modelled only on "man's reason". At this point, Hayek recalls Menger's criticism (and Leoni in turn did not mention Menger) of the "pragmatic" conception of social institutions ${ }^{55}$, reiterating how it is not reasonably possible to maintain that "morals, religion and law, language and writing, money and the market" have been "deliberately constructed by somebody" or derive from "such [a] design" 56 .

On this basis, Hayek links the errors of "constructivist rationalism" to "Cartesian dualism", or rather to the belief in the existence of a "mind substance which stands outside the cosmos of nature and which

55 C. MENGER, Untersuchungen, cit., p. 133ff. and pp. 187-189.

${ }^{56}$ F.A. HAYEK, Law, Legislation and Liberty, cit., I, pp. 8-10. He talks of the same social institutions mentioned by Menger, as we have seen, albeit in a different order. 
enables man, endowed with such a mind from the beginning, to design the institutions of a society and culture among which he lives". He compares this with a conception of the mind, developed by Mandeville and Hume, as "an adaption to the natural and social surroundings in which man lives and that has developed in constant interaction with the institutions which determine the structure of society". The mind is thus "the result of man having developed in society and having acquired those habits and practices that increased the chance of persistence of the group in which he lived" 57.

Hayek goes on - and here is the point - to deal with the "false dichotomy of 'natural' and 'artificial'", and the overcoming, attributed to Mandeville, Adam Ferguson, and Hume (thinkers not cited to those ends by Menger and Leoni), of the

"Misleading distinction which was introduced by the ancient Greeks and from whose confusing effect we have not yet wholly freed ourselves. [...]: the division of phenomena between those which in modern terms are 'natural' and those which are 'artificial'. The original Greek terms [...] were physei, which means 'by nature' and, in contrast to it, either nomos, best rendered as 'by convention', or thesei, which means roughly 'by deliberate decision'."58

More interesting than the differences between this Hayekian characterisation and the Leonian "famous opposition between vó $\mu$ os and $\varphi v ́ \sigma ı \varsigma^{\prime}$ is the fact that Hayek, adopting a Mengerian distinction (between two theories of the birth and development of institutions) that "may be either a distinction between objects which existed independently and objects which were the results of human action, or between objects which arose independently of, and objects which arose as the result of, human design", maintains that

"not until the eighteenth century did thinkers like Bernard Mandeville and David Hume make it clear that there existed a category of phenomena which, depending on which of the two definitions one adhered to, would fall into either the one or the other of the two categories and therefore ought to be assigned to a distinct third class of phenomena, later described by Adam Ferguson as "the

${ }^{57}$ F.A. HAYEK, Law, Legislation and Liberty, cit., I, p. 17.

58 F.A. HAYEK, Law, Legislation and Liberty, cit., I, p. 20. 
result of human action but not of human design'. These were the phenomena which required for their explanation a distinct body of theory and which came to provide the object of the theoretical social sciences" 59 .

Three considerations here present themselves. The first is that Hayek does not suggest that he was aware that this was also the solution which Leoni, in his Handouts, had seen as outlined in Epicureanism: Hayek was outlining an intellectual genealogy without a trace of Epicureanism. The second is that the influence of Epicureanism in Mandeville and Hume is much evident, above all in relation to religion and the origin of language and of institutions. The third is that this solution is also that of Menger.

Returning to Hayek, we can see how he numbers among the precursors of the individualism of "spontaneous cultural evolutionism": Aulus Gellius, the medieval schoolmen, "the Spanish Jesuits of the sixteenth century" and, among its most informed continuators and developers, Matthew Hale, Mandeville, Hume, Ferguson, Adam Smith, Burke, Wilhelm von Humboldt, Savigny, Sir Henry Maine, Charles Darwin and, above all, Menger, who gave to the theory a "genetic character" - though without mentioning that in the writings of Mandeville and Hume that evolutionism was of Epicurean descent ${ }^{60}$. This tradition, according to Hayek, had elaborated a conception of law that - like that of Leoni - set itself up against that proffered by Legal positivism which "is actually one of the main offshoots of that rationalist constructivism which, in taking literally the expression that man has 'made' all his culture and institutions, has been driven to the fiction that all law is the product of somebody's will" 61 .

The Hayekian distinction between 'cosmos'and 'taxis' is also of particular importance because it is linked to a definition of order as

\footnotetext{
"a state of affairs in which a multiplicity of elements of various kinds are so related to each other that we may learn from our acquaintance with some spatial or temporal part of the whole to form correct expectations concerning the rest, or at least expectations which have a good chance of proving correct" ${ }^{\prime \prime}$.
}

\footnotetext{
${ }^{59}$ F.A. HAYEK, Law, Legislation and Liberty, cit., I, p. 20.

${ }^{60}$ F.A. HAYEK, Law, Legislation and Liberty, cit., I, pp. 20-22.

${ }^{61}$ F.A. HAYEK, Law, Legislation and Liberty, cit., I, p. 28.

${ }^{62}$ F.A. HAYEK, Law, Legislation and Liberty, cit., I, p. $35 \mathrm{ff}$. .
} 
Having first described the utility of an order that has not been planned to facilitate predictions on the realisability of ever-changing human expectations, Hayek then returns to its origins. He traces these back to two different roots, both of Greek origin, and makes reference on the one hand to taxis, the idea of planned organisation, and on the other, to spontaneous order as "a right order in a state of a community: cosmos". Having reiterated (like Menger) that true social science begins "with and has an object only because of - the discovery that there exist orderly structures which are the product of the action of many men but are not the result of human design", Hayek moves on to describe the characteristics of "complex spontaneous orders", the peculiarity of which does not favour the particular goals of he who created them (taxis), but the quite different goals of those who use them (cosmos) ${ }^{63}$.

Having spoken of the "fundamental importance" of the distinction between the "coercive functions" of a government that produced the rules of conduct, and the workings of a government that limits itself to providing services, Hayek returns to the functioning of rules in spontaneous orders and organisations. Here he sees the reflection of a more general contrast between those who hold that "law and liberty could not exist apart from each other" and those who think that a "law, by necessity, means an encroachment on freedom" 64 . Then, having brushed over a topic that, as we have seen, was also tackled by Menger in the Untersuchungen, namely the "role of the lawyer in political evolution"65, Hayek returns to the question of the origin of law in Greece.

In this case, Hayek writes that "although the idea that law was the product of deliberate human will was first fully developed in ancient Greece, its influence on the actual practice of politics remained limited", while until the modern age "law was again regarded as

* The reference is to W. JAEger, Paideia. Die Formung des griechischen Menschen, Berlin und Leipzig, W. de Gruyter, 1934, pp. 156-57 n.9. In the course of the note, Hayek, demonstrating the distance of this tradition from Platonism and Aristotelianism, writes that for Aristotle, who links "nomos with taxis rather than cosmos", it was "characteristically inconceivable that the order resulting from the nomos should exceed what the order can survey".

${ }^{63}$ F.A. HAYEK, Law, Legislation and Liberty, cit., I, p. $37 \mathrm{ff}$.

${ }^{64}$ F.A. HAYEK, Law, Legislation and Liberty, cit., I, pp. 48-52.

65 F.A. HAYEK, Law, Legislation and Liberty, cit., I, p. $65 \mathrm{ff}$. 
something given independently of human will", something that had to be, if anything, "discovered" 66 rather than 'created' on the basis of 'customs' and 'precedents', as with the English Common Law ${ }^{67}$.

The most interesting part of the work is perhaps that in which Hayek returns to the topic of legislative corrections of spontaneous legal order, or "grown law", above all when "wholly new circumstances" emerge and make themselves felt. When this happens, given that the "judicial development of law is of necessity gradual and may prove too slow to bring about the desirable rapid alteration", an impasse can follow in which the system of order described earlier is overwhelmed, no longer able to manage individual and social expectations. This is even now, or perhaps now more than ever, a central question, because it leads us to consider the effects of the promptness or otherwise of the response of any institutional system (whether spontaneous or consciously designed) when confronted with a vast and continuous emergence of unforeseen circumstances and an equally unpredictable array of direct and unintended consequences that emerge from these. Demonstrating a great regard for Leoni's ideas but simultaneously registering his own disagreement, Hayek's response to this problem, contained in a note, cites Leoni as the "most persuasive interpreter" of the argument that "judicial decisions" needed to be trusted even in these circumstances, even if - and without denying their ability to better safeguard individual freedom - Hayek declared himself unconvinced that in such cases anything less than "deliberate legislation" would suffice. The need for legislation thus appears to Hayek, as it did for Menger though not for Leoni, motivated by the fact that "judicial decisions" may not only

66 This idea of a law that has to be 'discovered', a thing Hayek underlines several times, is, ultimately, that which sets the Hayekian theory of the birth of law apart, bringing it closer to the theory of Natural Right, and the theory of Epicurean (but also 'romanistic') origin, for which law is ultimately the result of a long and not always intentional process that does not have law's 'discovery' as its object.

${ }^{67}$ See F.A. HAYEK, Law, Legislation and Liberty, cit., I, pp. 82ff. It should here be remembered that F.A. HAYEK, in The Results Of Human Action but not of Human Design, now in F.A. HaYeK, Studies in Philosophy, Politics and Economics, cit., p. 99 n.10, writes that "Professor Bruno Leoni has drawn my attention to the fact that Hume's use of 'artificial' in this connection derives probably from Edward Coke's conception of law as 'artificial reason' which is of course closer to the meaning the later scholastics had given to 'natural' than to the usual meaning of 'artificial'." 
be slow in coming about, but also may be wrong-headed and harmful in situations other than those in which they were adopted 68 .

Finally, Hayek returns to the conception of the nomos in the Greek sense and that of the jus of the Roman jurists, distinguishing it from the lex as a norm of organisation. He returns to the role of judges in the defence of individual liberty, writing that every complex juridical system is

\begin{abstract}
"the outcome of a process of evolution in the course of which spontaneous growth of customs and deliberate improvements of the particulars of an existing system have constantly interacted [...] No system of law has ever been designed as a whole, and even the various attempts at codification could do no more than systematize an existing body of law and in doing so supplement it or eliminate inconsistencies"69.
\end{abstract}

We can thus conclude this exposition, as much of the similarities as of the differences between the Leonian thesis and the Hayekian one

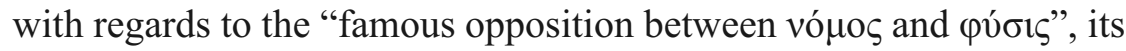
implications, and its development, by recalling that Hayek's distinction between "rules of just conduct which emerge from the judicial process, the nomos or law of liberty [...] and the rules of organization laid down by authority" for specific ends, consists of the fact that "the former are discovered" while the "rules of organization aiming at particular results will be free inventions of the designing mind of the organizer". Without going further at this point into what it would mean in real terms that laws are "discovered" and if they have anything to do with the Mengerian "exact laws" or "exact laws of nature" [exacte Gesetze or exacte Naturgesetze], we can observe that this distinction reflects "the difference in meaning between 'law' as it applied to the nomos and 'law' as it is used for all the other theses which emerge from legislation". This difference ensures that "whenever we speak of 'carrying out a law' we mean by the term 'law' not a nomos but a thesis instructing somebody to do particular things". It is therefore a difference that cannot be invalidated even if "a statute (thesis) passed by a legislature may have all the attributes of a nomos, and is likely to have them if deliberately modeled after the Nomos" 7 .

${ }^{68}$ F.A. HAYEK, Law, Legislation and Liberty, cit., I, pp. 88ff., and note 35 at p. 168.

${ }^{69}$ F.A. HAYEK, Law, Legislation and Liberty, cit., I, pp. 94-100.

${ }^{70}$ F.A. HAYEK, Law, Legislation and Liberty, cit., I, pp. 122-127. 


\section{Conclusions}

The substantial difference between Menger, Leoni, and Hayek lies in whether the "jurisprudential" juridical system or the "legislative" one provides a more timely guarantee of the functionality of an order (in a Hayekian sense, that is, as an instrument for the realisation over time of the greatest number of individual expectations) when "new circumstances" emerge, while simultaneously guaranteeing individual liberty.

That said - and remembering that their bibliographic references are different - it should be recognised that Hayek could have been prompted to adopt the terms cosmos, nomos, physis, and thesis (terms that don't appear in his previous works) from his reading of the "lithographed" Handouts, as well as from correspondence and conversations with Leoni. That which appears decidedly more interesting, however, is that the outcome of the resolution of the nomosphysis antithesis that Leoni attributes to Epicurus - a reconciliation in which it is demonstrated that from single 'contracts' between individuals drawn up to regulate specific situations (that if aimed at meeting needs one might refer to as 'exchanges' 71 ) ever more complex institutions can develop unintentionally that do not have specific ends 72 (the examples of the origin of language and of Law as distinct from laws being the most fitting) - appears, in its essential aspects, analogous to that which Hayek attributes to Mandeville, Hume, Ferguson, and Menger.

${ }^{71}$ See C. Menger, Grundsätze der Volkswirthschaftslehre, Wien, Wilhelm Braumüller, 1871, now in The Collected Works of Carl Menger, cit., II, pp. 153ss.; Engl. transl., Principles of Economics, with an Introduction by F.A. HAYEK, New York-London, New York University Press, 1981, pp. 175ff.

72 Precisely because he makes no reference to Hayek, Morel's opinion on this point deserves mention: P.-M. MOREL, in "Alle origini del contrattualismo. La concezione epicurea del giusto tra natura e convenzione", in Iride, 2015, XXVIII, p. 578, in which he synthesises this 'resolution' as follows: "the genealogy of institutions allows us therefore to understand how and why the Epicureans intend to overcome the antithesis between nature and convention. It also allows us to evaluate the conditions of legitimate politics, i.e. of a way of organising human communities that, without being comparable to a pure natural phenomenon, is not contrary to nature". Leoni and Hayek would have only substituted "a way of organising human communities" here with "a way of human communities organising themselves". 
This is a thesis of the birth of institutions in which the outcomes of human actions are not the consequences of their intentions or ends (the Fergusonian institutions" and the "organic-unintended" social institutions of Menger: language, religion, Right or Law, State, money and markets, etc., that - as we have seen - arose in "epochs of history where we cannot properly speak of a purposeful activity of the community as such directed at establishing them"73), but are rather the possible result of the interaction of the ends and actions of individuals and of rules that become mixed up and change over time. This allows an indefinite number of individuals which respect those rules to reach different ends which are not specified within a model of 'Hayekian order'. This was a theory that an Epicurean who knew the doctrine of clinamen would not have had difficulty in understanding (perhaps adding only a sarcastic 'eureka!') but that Plato and Aristotle would not have understood, or would have rejected.

In this way, the traditional nomos-physis antithesis, this time in the variant cosmos (spontaneous order) and taxis (organization), ends up being harmonised and restated as a distinction which Hayek, in the wake of Michael Oakeshott, saw as existing between a "nomocratic regime" or "nomocracy" understood as "spontaneous order" and a "teleocratic regime" or "teleocracy", understood as a "made order or organisation", in which "the same hierarchy of ends is binding on all members"74. This is a distinction which is analogous to the Mengerian distinction between "organic-unintended institutions" and "pragmatic institutions", and to Leoni's dichotomy between "Common Lawmarket" on the one hand and "legislation-planning" on the other 75 .

It is true that many, though certainly not all of the most important

${ }^{73}$ Cfr. C. Menger, Untersuchungen, cit., p. 163; Engl. transl. cit., p. 146.

${ }^{74}$ See F.A. HAYEK, The Mirage of Social Justice, in F.A. HAYEK, "Law, Legislation and Liberty", cit. II, p. 15, and F.A. HAYEK, New Studies in Philosophy, Politics, Economics and the History of Ideas, London, Routledge, 1978, p. 89, where Hayek writes about using terms that Oakeshott was repeating in his lessons (and that actually don't appear in M. Oakeshott, On Human Conduct, Oxford, Clarendon, 1975, where that dichotomy is developed using different terminology), cfr. M. OAKESHOTT, Lectures in the History of Political Thought, ed. by T. NARdin, L. O’Sullivan, Exeter, Imprint Academic, 2006, p. 469ff.. With regards to the literature, though without mention of Leoni and Epicureanism, see C.-Y. Cheung, Hayek on Nomocracy and Teleocracy: A Critical Assessment, in "Cosmos and Taxis", 2014, I/2, pp. 24-33.

${ }^{75}$ See B. LeOnI, Freedom and the Law, cit., pp. $21 \mathrm{ff}$. . 
exponents of the tradition of "true Individualism" 6 do not talk of Epicurus or Epicureanism, and even Leoni himself seems to have forgotten them. Others certainly did not possess editions of the texts and Epicurean fragments collected by Usener 77 and Bignone, though they may have read Cicero, Diogenes Laërtius, or Lucretius, and it almost goes without saying that no one was able to escape the aura of infamy that surrounded a tradition which for centuries was understood as the principal enemy of the Judeo-Christian religion. It is thus truly strange that, being atheists or sceptics in religious matters, these theorists should not have realised the potentiality of Epicurean doctrine, demonstrating in this respect more ignorance, or maybe less courage than Hobbes, Mandeville, or Hume. It may be that, like Machiavelli, they wanted to avoid becoming mixed up in theological discussions that would have certainly encumbered the diffusion of a theory that they were presenting as new and revolutionary but that was substantially, whether they were aware of it or not, a restatement of Epicurean ideas.

Here we might ask why Leoni did not pay more attention to that which is claimed was of "exceptional importance" for the history of western juridical and political thought, or from what previous knowledge he derived that judgment ${ }^{78}$. It could be that its 'importance' was linked to the usefulness of the Epicurean solution of the infamous antithesis in confronting the ever present problem of the contrast between positive law or legislation and common law and the reasons for obeying the former, a problem towards which Leoni was anything but indifferent. It is a great shame that, at this point, it is not possible to go on to discuss the Leoni's relationship between contract and claim.

\footnotetext{
${ }^{76}$ For the most important exponents of "false Individualism", it will suffice to recall references to Epicureanism on the part of English Utilitarianism or Hedonism.

77 See H. UsEner, Epicurea, Lipsiae, B.G. Teubneri, 1887.

${ }^{78}$ In the authors which he cites and also in the essay by R. Philippson, Die Rechtsphilosophie der Epikureer, in "Archiv für Geschichte der Philosophie", n.s. 1910, XXIII, pp. 289-337, 433-46, there is in fact no attention paid to the juridico-political projection of Epicureanism, unlike that which we find in Guyau and Brochard. There now exists a wide range of literature on this topic.
} 
Riassunto - Nel 1949, mettendo a disposizione degli studenti pavesi di Giurisprudenza delle Dispense dal titolo Il pensiero antico, Bruno Leoni non immaginava che stava contribuendo a porre le basi per una riformulazione di quella che nello stesso anno Friedrich A. von Hayek aveva chiamato la tradizione del "true Individualism" tracciando così una nuova storia delle origini e dello sviluppo della tradizione liberale. Infatti, dopo aver descritto l'origine dei concetti di nomos e di physis nella filosofia greca, in quelle Dispense Leoni intende la soluzione epicurea e la sua dottrina del contratto come un qualcosa di "eccezionale importanza per lo sviluppo della speculazione intorno al diritto ed allo Stato nell'età moderna". Accennato all'impor- tanza che negli stessi anni Ludwig von Mises e Leo Strauss attribuiranno all'Epicureismo nella nascita della 'modernità, il saggio analizza la tesi leoniana sul rapporto tra nomos e physis e, illustratane l'affinità con la tesi di Carl Menger sulla nascita "irriflessa" delle principali istituzioni sociali e del diritto, mostra il modo in cui tale rapporto ha influenzato Hayek e come si rifletta nella di lui (e di Michael Oakeshott) dicotomia tra i modelli istituzionali 'nomocratici' e quelli 'teleocratici'. Un breve cenno, nel finale, al modo in cui tracce della dottrina epicurea del contratto possono essere ravvisate nella teoria dello "scambio di pretese" che Leoni pone all'origine del diritto. 